\title{
Driving transformation performance through innovation and experience model
}

\author{
Marindra Bawono $^{a^{*}}$ and Leonardus W.W. Mihardjo ${ }^{a}$
}

\begin{tabular}{|c|c|}
\hline CHRON I C L E & A B S T RACT \\
\hline $\begin{array}{l}\text { Article history: } \\
\text { Received: October 26, } 2019 \\
\text { Received in revised format: No- } \\
\text { vember } 212019 \\
\text { Accepted: November } 25,2019 \\
\text { Available online: } \\
\text { November } 25,2019\end{array}$ & $\begin{array}{l}\text { Innovation on business model is not only describing the bundle of products and services but also it } \\
\text { is integrated with the input of customer experience. Customer experience should become a key role } \\
\text { in developing business model innovation in driving transformational performance. This paper ar- } \\
\text { gues that the transformational performance is derived from business model innovation and focuses } \\
\text { on customer experience. We use telecommunication firms as our unit analysis with sample of } 195 \\
\text { Indonesian ICT firms out of } 542 \text { units. The analytical approach and solution technique that is used }\end{array}$ \\
\hline $\begin{array}{l}\text { Keywords: } \\
\text { Transformational Performance } \\
\text { Business Model Innovation } \\
\text { Customer experience } \\
\text { Industry } 4.0\end{array}$ & $\begin{array}{l}\text { for analysis is Partial Least Square (PLS). The findings demonstrate that business model played } \\
\text { significant role on supporting contribution of customer experience in driving transformational per- } \\
\text { formance. The finding has implication that by synergizing the value proposition of customer expe- } \\
\text { rience in a business model innovation, the transformational performance can be maintained through } \\
\text { focus on customer experience driven business model innovation. Further study can be explored } \\
\text { through additional variable, sample and further study on longitudinal on digital transformation } \\
\text { firms. }\end{array}$ \\
\hline
\end{tabular}

\section{Introduction}

\subsection{Research Background}

The digital technology as part of Information and Communication Technologies (ICT) infrastructures drive the fusion of industrial production. The virtualization and digitalization bring the convergences between the physical and the virtual worlds (Ibarra et al., 2018). Hence those convergences enable the transformation of ecosystem and business model to become a smart connected solution (Heppelmann, 2014). Those phenomenon is called industrial resolution 4.0 that rely on conceptual model based on business model innovation (Kagermann, 2015; Pink, 2005). The industry 4.0 emphasis the change in the way to do business through transformation business, people, culture and organization. The transformation is enable the management to rethink the existing business model innovation (Berman, 2012; Schwertner, 2017), since the business model innovation is related with value creation, it brings extensive consequences and opportunities (Amit \& Zott, 2010; Basceanu, 2014; Zott \& Amit, 2017). The key success implementation of business model innovation is customer, especially customer experience in digital era (IBM, 2017; Seppanen \& Laukkanen, 2015). Customer experience is the center for the input in development of business model innovation to drive the performance (Fatma, 2014). The performance in digital transformation shall ensure the new paradigm and potential service for future can be measured with the existing performance. The measurement of success in transformation is constructed from the performance management theory with the concept of transformation (Wei \& Xuexun, 2010). we argue that development of business model innovation based on customer experience is driving the transformational performance. The previous literature has been exploring the construct, applicability and benefit of business model innovation based on customer experience and impact relationship to performance, however the study in emphasizing the transformational

* Corresponding author.

E-mail address: marindra.b@gmail.com (M. Bawono) 
performance associated with performance management during the transformation stage in conjunction with business model innovation based on customer experience has not been explored. The Indonesia ICT market is quite unique to be analyzed. The benefit of demography based on its population, age and natural resources should put Indonesia as a promising country to grow. However, According to Das et al. (2016) Indonesia is categorized as a country in an early stage of digital ICT development. But in terms of innovation, Indonesia is considered as the country with the highest rate of digital innovation and startup players (Mastercard and Fletcher School at Tuft University, 2017). Hence the study on ICT Indonesia market is taking important role to minimize gap of contribution digital ICT into country competitiveness development.

The aim of this paper is to present a transformational performance determined by business model innovation based on customer experience and relationship among the variable. The empirical study has the goals to develop transformational model as impacts from business models focused on customer experience and to identify the strong factor of business model innovations and customer experience in driving transformational performance.

\section{Literature Review}

\subsection{Transformational Performance}

Transformational performance is constructed from combination of performance management theory and transformation concept. The transformational performance shall define key success of the firm to ensure the company could transform into new paradigm and change the behavior of organization (Spitzer, 2007). Hence the transformational performance shall measure the process of transformation journey, start from current performance (short term view), long term view related with innovation and potential future service (Wei \& Xuexun, 2010) and the measurement of changing ecosystem especially in digital era (Valdez-de-leon, 2016; Weill \& Woerner, 2015). According the study literature, transformational performance will be measured through the dimensions of existing performance, potential performance and ecosystem maturity.

\subsection{Business Model Innovation}

Business model Innovation is related with value creation (Amit \& Zott, 2010; Basceanu, 2014; Zott \& Amit, 2017). In digital transformation, business model innovation becomes popular (Berman, 2012; Li, 2018; Prem, 2015). In digital era, business model innovation consists of value dimension in terms of efficiency, look in to the business and customers, complementary solution, and novelty of the innovation created from the business model (Amit \& Zott, 2001; Zott \& Amit, 2010). Those 4 indicators are parts of source of value creation as impact of implementation of business model innovation, where the value is determined from business model structure, business model content and business model governance (Amit \& Zott, 2001; Zott $\&$ Amit, 2010). This study uses the dimensions of business model innovation constructed by Zott (2010) which are business model structure, content and governance

\subsection{Customer Experience}

Customer experience is part of customer journey (Lemon \& Verhoef, 2016). It emphasizes on customer personality in having relationship with the company. It consists of multidimensional view, including the process, brand, and perception., This also includes sensory (sense), affective (feeling), cognitive (thinking), physical (act), and social-identity (relation) experiences (Bolton, 2016). Personalization is a key success, especially when the digital technology is applied where trust is the main driver (Henfridsson et al., 2014). Customer experience is a process that involves the entire experience of customers having an interaction with lifecycle customers. Customer experience is constructed in a holistic manner related to the customer's cognitive, affective, emotional, social, and physical responses. In retailing context, customer experiences can be categorized along the lines of the retail mix (i.e., price experience, promotion experience) (Grewal et al., 2009). Based on the literature review, customer experience in this study is measured by dimensions of price and promotion, CRM \& data analytics, trust \& personalization, and brand performance.

\subsection{Hypothesis Development}

The customer experience has positive relationship to support the company performance based on the previous study (Fatma, 2014; Stuart \& Tax, 2004). It will drive the better performance in terms of brand, customer satisfaction and will impact to financial performance, hence we develop the hypothesis as follow:

Hypothesis 1: Customer experience has positive influence on transformational performance in the Indonesian ICT industry.

Customer experience as the input in developing business model innovation has positive influence in developing business innovation (Gilmore \& Pine, 2002; IBM, 2017; Seppanen \& Laukkanen, 2015). The feedback from customer is a better input in developing business model innovation in facing disruptive era, hence the second hypothesis could be developed as follow:

Hypothesis 2: Customer experience has positive influence on business model innovation in the Indonesian ICT industry.

Business model innovation has forced the firm to perform the innovation hence it will influence to the value creation and performance (Amit \& Zott, 2010; Cucculelli \& Bettinelli, 2015; Schaltegger et al., 2016).

Hypothesis 3: Business model innovation has significant influence on transformational performance in the Indonesian ICT industry.

Based on the hypothesis development, the research model can be shown in Fig. 1. 


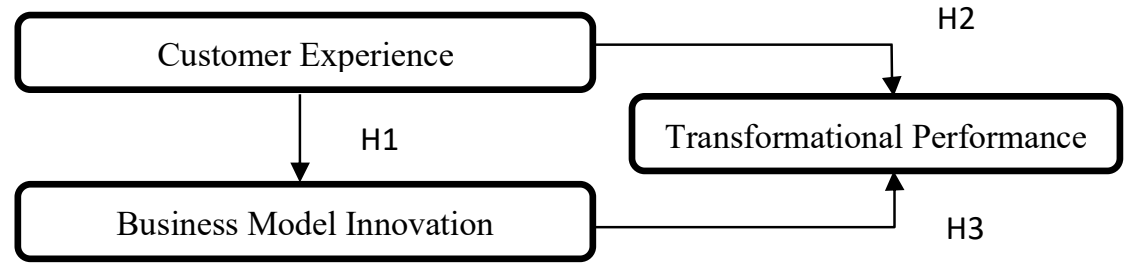

\section{Methodology}

Fig. 1. The Research Model Framework

The unit analysis is Indonesia ICT Firm. This study was conducted through survey on 195 Indonesian ICT firms out of 542 ICT population firms. The sample included the network and service provider firms. Those sampling number is higher than minimum request sample of 33 respondents for the model with an endogenous construct has 2 arrows directed, $5 \%$ Probability error, $80 \%$ statistical power and minimum $\mathrm{R}^{2}=0.25$ (Cohen, 1992). Purposive sampling is also used. The survey was conducted from June to August 2019, analytical tool and solution technique uses smart PLS. The distributed respondents are as follow:

\section{Table 1}

Sample Respondents

\begin{tabular}{|c|c|c|c|c|}
\hline Segment & Board/C Level & VP Levels & GM Level & Mgr Level \\
\hline Network Provider & 17 & 89 & 17 & 6 \\
\hline Service Provider & 11 & 6 & 17 & 0 \\
\hline Partners & 22 & 0 & 5 & 5 \\
\hline TOTAL & 50 & 95 & 39 & 11 \\
\hline
\end{tabular}

In our survey, $65 \%$ of the respondents are network provider, while $17 \%$ service provider and the rest of $17 \%$ are partners who support network and service providers.

\section{Result}

\subsubsection{Measurement Model (outer model)}

the outer model is used to assess the relationship between latent variables and their indicators. The test performs the construct validity based on Average Variance Extracted (AVE) with Expected value $>0.5$., while the reliability can be tested through Composite reliability and Cronbach's Alpha of variables $>0.70$.

Table 2

Construct Reliability and Validity

\begin{tabular}{|c|c|c|c|}
\hline & Cronbach's Alpha & rho A & AVE \\
\hline Business Model Innovation & 0.942 & 0.950 & 0.720 \\
\hline Content Innovation & 0.956 & 0.959 & 0.919 \\
\hline Structure Innovation & 0.809 & 0.855 & 0.731 \\
\hline Governance Innovation & 0.816 & 0.830 & 0.843 \\
\hline Customer Experience & 0.909 & 0.912 & 0.501 \\
\hline Brand Performance & 0.908 & 0.910 & 0.784 \\
\hline Customer Relation & 0.792 & 0.799 & 0.704 \\
\hline Price & 0.705 & 0.706 & 0.772 \\
\hline Trust Personalization & 0.793 & 0.801 & 0.712 \\
\hline Transformational Performance & 0.927 & 0.934 & 0.586 \\
\hline Existing & 0.836 & 0.850 & 0.605 \\
\hline Ecosystem & 0.759 & 0.764 & 0.673 \\
\hline Potential & 0.932 & 0.932 & 0.880 \\
\hline
\end{tabular}

Table 2 shows the result is higher than the expected value, hence all variables and dimensions are valid. Discriminant validity to assess whether the model is correlated or not has also been performed. The result shows that the diagonal bold numbers are bigger than horizontally listed numbers, which means the measurement model has good discriminant validity.

Table 3

Discriminant Validity

\begin{tabular}{clcc}
\hline No & Variable & 1 & 2 \\
\hline 1 & Business Model Innovation & 0.849 & \\
2 & Customer Experience & 0.708 & 0.766 \\
3 & Transformational Performance & 0.766 & 0.712 \\
\hline
\end{tabular}

The value of convergent validity is the value of the loading factor of outer path analysis. $t$ value $>t$ table (1.96) and $p$ value $<0.05$ which means each indicator is a valid. The result demonstrates the latent variable dimension and indicators are valid. 
Table 4

Loading Factor of Latent Variable-Dimension-Indicator

\begin{tabular}{|c|c|c|c|c|}
\hline & Path & $\mathrm{SD}$ & T-Stat & P Values \\
\hline Business Model Innovation $\rightarrow$ Content Innovation & 0.955 & 0.033 & 28.717 & 0.000 \\
\hline Business Model Innovation $\rightarrow$ Governance Innovation & 0.880 & 0.052 & 16.891 & 0.000 \\
\hline Business Model Innovation $\rightarrow$ Structure Innovation & 0.944 & 0.024 & 40.076 & 0.000 \\
\hline Customer Experience $\rightarrow$ Brand Perf. & 0.793 & 0.117 & 6.768 & 0.000 \\
\hline Customer Experience $\rightarrow$ Customer Relation & 0.859 & 0.039 & 21.768 & 0.000 \\
\hline Customer Experience $\rightarrow$ Price & 0.770 & 0.117 & 6.586 & 0.000 \\
\hline Customer Experience $\rightarrow$ Trust Personalization & 0.869 & 0.059 & 14.745 & 0.000 \\
\hline Transformational Performance $\rightarrow$ Ecosystem & 0.897 & 0.037 & 24.245 & 0.000 \\
\hline Transformational Performance $\rightarrow$ Existing & 0.950 & 0.013 & 73.391 & 0.000 \\
\hline Transformational Performance $\rightarrow$ Potential & 0.898 & 0.030 & 30.398 & 0.000 \\
\hline
\end{tabular}

\subsubsection{Structural Model and Hypothesis Testing}

Fig. 2 shows the complete path diagram based on structural model testing:

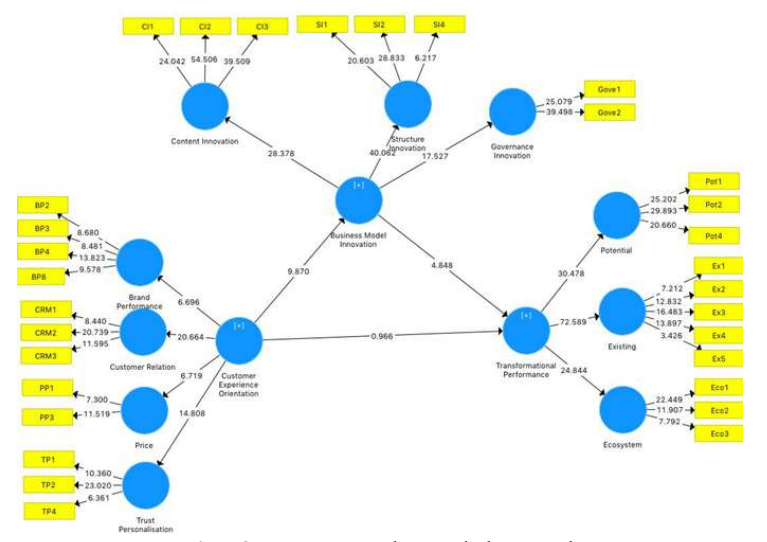

Fig. 2. Structural Model Result

\subsection{Hypothesis testing}

Simultaneous Hypothesis testing

Below is the result of simultaneous testing of the hypothesis:

Table 5

Simultaneous Testing of Hypothesis

\begin{tabular}{cccc}
\hline Hypothesis & T-Stat & P Value & Conclusion \\
\hline Customer Experience $\rightarrow$ Business Model Innovation $\rightarrow$ Transformational Performance & 4.546 & 0.000 & Hypothesis accepted \\
\hline
\end{tabular}

* significant at T-Statistics $>1.96(\mathrm{P}-$ Value $<0.05)$

The result of Table 5 shows for simultaneous hypothesis testing is accepted which means business model innovation plays intervening roles on relationship between customer experience and transformational performance.

Partial Hypothesis testing

The result of partial testing of the hypothesis is as follow:

Table 6

$\underline{\text { Partial Testing of Hypothesis }}$

\begin{tabular}{lrcccc}
\multicolumn{1}{c}{ Hypothesis } & $\gamma$ & SE $(\gamma)$ & T-Stat & P-Value & Conclusion \\
\hline CUSTOMER EXP $\rightarrow$ BUS MODEL INNOVATION & 0.766 & 0.075 & 10.213 & 0.000 & Hypothesis accepted \\
CUSTOMER EXP $\rightarrow$ TRANSFORMATIONAL PERF & 0.163 & 0.171 & 0.957 & 0.339 & Hypothesis Not ac- \\
BUSS MODEL INNOVATION $\rightarrow$ TRANSFORMATIONAL PERF & 0.717 & 0.150 & 4.762 & 0.000 & Hypothesis accepted \\
\hline
\end{tabular}

* significant at T-Statistics $>1.96(\mathrm{P}-$ Value $<0.05)$

\section{Discussion and Implication}

Based on the finding on structural test in hypothesis testing we understand that the business model innovation plays important role in transformations as an intervening role on relationship between customer experience and transformational performance. Business model innovation was strongly constructed by content and structure innovation while governance innovation was less significant compared with other dimensions. The finding strengthening the previous studies about the creativity behavior in innovation which is required to have governance role (Wang et al., 2008). Based on the partial hypothesis testing, the findings can be represented that customer experience has indirect influence on transformational performance not directly 
influence on transformational performance. It means that customer experience is an input for further innovation in business model to create product and service based on customer feedback. The finding shows the development of customer experience is constructed by customer relation and personalization. This finding strengthen the previous studies on customer relation through physical and virtual connectivity to provide trust and personalization to customers (Brakus et al., 2009; Parise et al., 2016). The finding also shows the important of current performance during the transformation as the main factor in assure that the transformation is having supported by management and employee and prove to the stakeholder that the development of future product could not impact to current performance. This finding is supported ambidextrous concept in allocation innovation for existing and future (Gurtner \& Reinhardt, 2016)

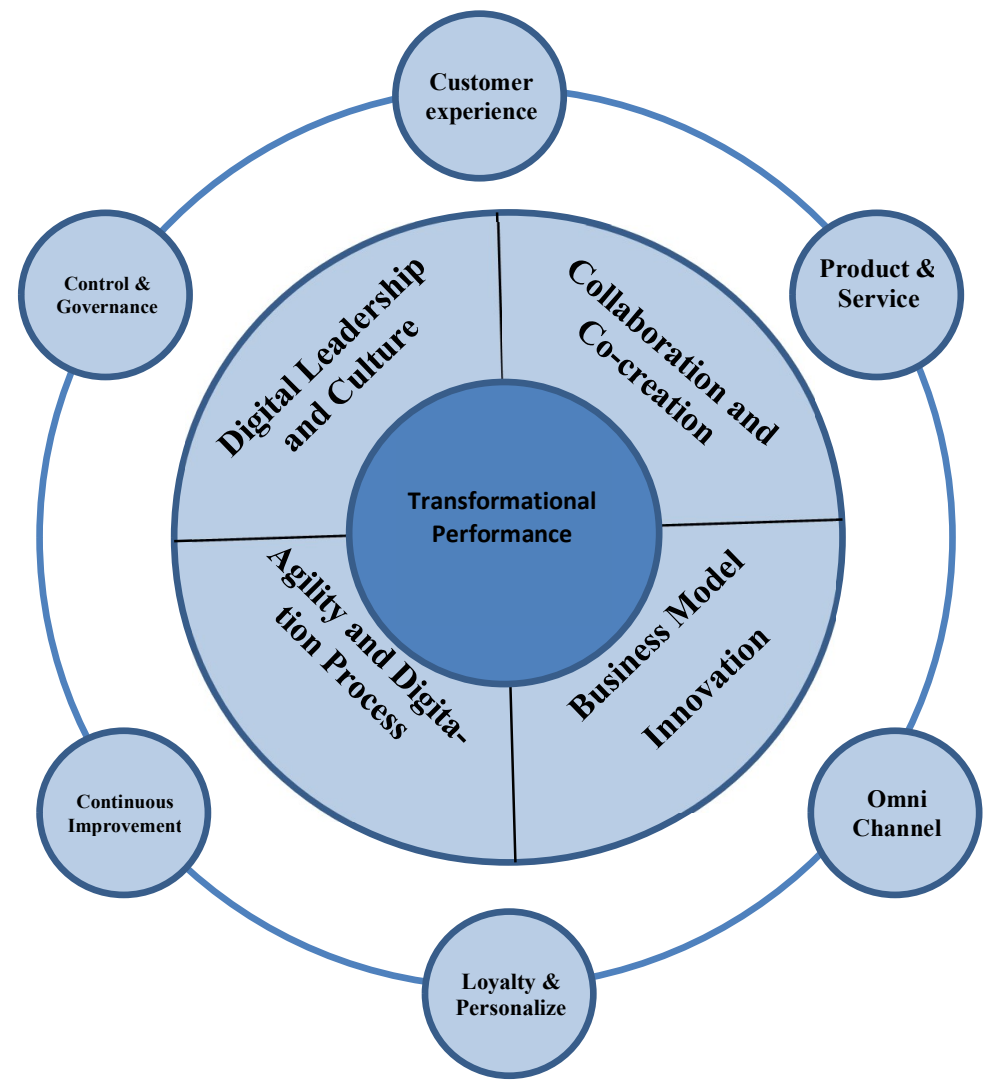

Fig. 3. Business Model innovation based on customer experience model (Saracco, 2017)

This is having implication for practitioner in developing transformational performance rely on the development based on customer experience as the input for collaboration and co-creation in product and service, increase business model innovation for product, sales, marketing and customer relation through omni channel or physical and digital distribution channel through community and social media. The loyalty through empowerment of data analytical need to create personalize offer for future product and service in terms agility and digitation process to support continuous improvement and fastest decision making while leadership and culture is the element to control the quality and delivery to match with customer experience and to integrate the respective parties and process into internal capability and process. The transformation model can be shown in Fig. 3.

\section{Conclusion and Recommendation}

The business model has played significant role in transformation as an intervening role between customer experience and transformational performance. Customer experience has indirect influence on transformational performance through business model innovation. The study has limitations on time, model, sample and tool. Hence, further study could expand into holistic model, longitudinal study for investigate the role of business model and customer experience in digital transformation, better statistical tool and expanding the sample.

\section{References}

Amit, R., \& Zott, C. (2001). Value Creation in E-Business. Strategic Management Journal, 22, 493-520.

Amit, R., \& Zott, C. (2010). Business Model Innovation: Creating Value In Times Of Change. Universia Business Review (Vol. 3 ). https://doi.org/10.2139/ssrn.1701660

Basceanu, L. (2014). Business Model Innovation and Value Co-Creation - based on a single case study on Liz Claiborne -. Retrieved from http://studenttheses.cbs.dk/bitstream/handle/10417/4570/lelia_ecaterina_basceanupdf.pdf?sequence=1

Berman, S. J. (2012). Digital transformation: Opportunities to create new business models. Strategy and Leadership, 40(2), 16-24. Bolton, R. N. (2016). Service excellence: Creating customer experiences that build relationships. (N. Maholtra, Ed.). New York: 
Business Expert Press, LLC. Retrieved from http://www.ruthnbolton.com/Webinar160915_Bolton.pdf

Brakus, J. J., Schmitt, B. H., \& Zarantonello, L. (2009). Brand experience: What is it? How is it Measured? Does it affect loyalty? Journal of Marketing, 73(3), 52-68.

Cohen, J. (1992). Quantitative Methods in psychology: A Power Primer. Psychological Bulletin, 112(1), 155-159.

Cucculelli, M., \& Bettinelli, C. (2015). Business models, intangibles and firm performance: evidence on corporate entrepreneurship from Italian manufacturing SMEs. Small Business Economics, 45(2), 329-350.

Das, K., Gryseels, M., Sudhir, P. and Tan, K. (2016) Unlocking Indonesia's Digital Opportunity, Mckinsey.

Fatma, S. (2014). Antecedents and consequences of customer experience management- A literature review and research agenda. International Journal of Business and Commerce, 3(6), 32-49.

Gilmore, J. H., \& Pine, B. J. (2002). Customer experience places: The new offering frontier. Strategy \& Leadership, 30(4), 4-11.

Grewal, D., Levy, M., \& Kumar, V. (2009). Customer experience management retailing an organizing framework. Journal of Retailing, 85(1), 1-14.

Gurtner, S., \& Reinhardt, R. (2016). Ambidextrous idea generation-Antecedents and outcomes. Journal of Product Innovation Management, 33, 34-54.

Henfridsson, O., Mathiassen, L., \& Svahn, F. (2014). Managing technological change in the digital age: The role of architectural frames. Journal of Information Technology, 29(1), 27-43.

Heppelmann, J. E. (2014). How Smart, Connected Products Are Transforming Competition, (November). https://doi.org/10.1017/CBO9781107415324.004

Ibarra, D., Ganzarain, J., \& Igartua, J. I. (2018). Business model innovation through Industry 4.0: A review. Procedia Manufacturing, 22, 4-10. https://doi.org/10.1016/j.promfg.2018.03.002

IBM. (2017). Victorious or vanquished? digital Reinvention in telecommunications.

Schwertner, K. (2017). Digital Transformation of Business Models. Trakia Journal of Science, 15(1), 388-393.

Kagermann, H. (2015). Change through digitization-value creation in the age of industry 4.0. In Management of Permanent Change (pp. 23-32). https://doi.org/10.1007/978-3-658-05014-6 2

Lemon, K. N., \& Verhoef, P. C. (2016). Understanding customer experience throughout the customer journey. Journal of Marketing, 80(6), 69-96.

Li, F. (2018). The digital transformation of business models in the creative industries: A holistic framework and emerging trends. Technovation, (January), 1-10. https://doi.org/10.1016/j.technovation.2017.12.004

Mastercard and Fletcher School at Tuft University (2017) Introduction https://www.mastercard.us/en-us/governments/insights-research/digital-evolutionindex/introduction.html

Parise, S., Guinan, P. J., \& Kafka, R. (2016). Solving the crisis of immediacy: How digital technology can transform the customer experience. Business Horizons, 59(4), 411-420.

Pink, D. (2005). A Whole New Mind: Why Right-Brainers Will Rule The Future. Penguin Group (USA) Inc. Retrieved from http://www.danpink.com/wnm.html

Prem, E. (2015). A digital transformation business model for innovation. The Proceedings of The 2015 ISPIM Innovation Summit in Brisbane, Australia - 6-9 December 2015, (December 2015). Retrieved from http://www.ispim.org/abstracts/The Proceedings of The 2015 ISPIM Innovation Summit, Brisbane, Australia - 6-9 December 2015/prem_erich.html

Saracco, R. (2017). Digital transformation. Retrieved from http://sites.ieee.org/futuredirections/category/blog/

Schaltegger, S., Lüdeke-Freund, F., \& Hansen, E. G. (2016). Business Models for Sustainability: A Co-Evolutionary Analysis of Sustainable Entrepreneurship, Innovation, and Transformation. Organization and Environment, 29(3), $264-289$.

Seppanen, M., \& Laukkanen, I. (2015). Business model innovation: Focus on customer experience. In 2015 IEEE International Conference on Engineering, Technology and Innovation/International Technology Management Conference, ICE/ITMC 2015. https://doi.org/10.1109/ICE.2015.7438657

Spitzer, D. R. (2007). Transforming Performance Measurement: Rethinking How You and Your Organization Use Measurement. Measurement, 288.

Stuart, F. I., \& Tax, S. (2004). Toward an integrative approach to designing service experiences Lessons learned from the theatre. Journal of Operations Management, 22(6), 609-627.

Valdez-de-leon, O. (2016). A Digital Maturity Model for Telecommunications Service Providers A Digital Maturity Model for Telecommunications Service Providers, 6(8), 19-32.

Wang, Q., Bradford, K., Xu, J., \& Weitz, B. (2008). Creativity in buyer-seller relationships: The role of governance. International Journal of Research in Marketing, 25(2), 109-118.

Wei, Z., \& Xuexun, H. (2010). A research on the relationship between innovation culture, transformational capabilities and transformational performance. In 2010 International Conference on Management and Service Science, MASS 2010.

Weill, P., \& Woerner, S. L. (2015). Thriving in an Increasingly Digital Ecosystem. MIT Sloan Management Review, 56(4), $27-34$.

Zott, C., \& Amit, R. (2010). Business model design: An activity system perspective. Long Range Planning, 43(2-3), 216-226.

Zott, C., \& Amit, R. (2017). Business model innovation: How to create value in a digital world. GfK Marketing Intelligence Review, $9(1), 18-23$.

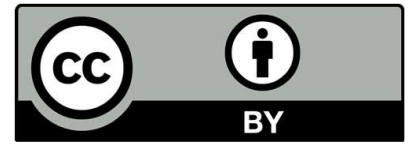

(C) 2020 by the authors; licensee Growing Science, Canada. This is an open access article distributed under the terms and conditions of the Creative Commons Attribution (CC-BY) license (http://creativecommons.org/licenses/by/4.0/). 